\title{
FIRST RECORD OF TWO TRICHODINID ECTOPARASITES (CILIOPHORA: TRICHODINIDAE) FROM CHITTAGONG, BANGLADESH
}

\author{
Asmat, G. S. M., L. Naher ${ }^{1}$, N. Sultana ${ }^{2}$ and M. M. A. Habib ${ }^{3}$ \\ Department of Zoology, University of Chittagong, Chittagong 4331, Bangladesh; ${ }^{1}$ Motijheel Ideal \\ School and College, Dhaka 1000, Bangladesh; ${ }^{2}$ Youngone Group Ltd., Chittagong EPZ, Chittagong, \\ Bangladesh; ${ }^{3}$ Department of Biology, Notre Dame College, Motijheel Circular Road, Arambagh, \\ Motijheel, Dhaka 1000, Bangladesh
}

\begin{abstract}
During parasitological surveys in Chittagong, Bangladesh two species of trichodinid ectoparasites belonging to the genera Tripartiella Lom, 1959 and Trichodina Ehrenberg, 1830 were collected from the gills of Rita rita (Hamilton, 1822) and Channa striata (Bloch, 1793) from January to December 2001. Tripartiella orthodens Basson and Van As, 1987 was recorded from the gills of $R$. rita in the Karnaphuli River systems, and Trichodina cobitis Lom, 1961 from C. striata in a household pond. Description, photomicrographs and morphometric data of these ciliates are provided along with their prevalence and intensity of infection.
\end{abstract}

Key words: Tripartiella orthodens, Trichodina cobitis, Karnaphuli River, Bangladesh.

\section{INTRODUCTION}

To date, more than 350 species of trichodinid ciliates have been recorded from different countries. However, a very small number of them have been studied in Bangladesh so far. Work on this group in Bangladesh got momentum since 2003. As a result, 15 new and 21 known species of trichodinid ciliates of the genera Paratrichodina Lom, 1963; Trichodina Ehrenberg, 1830; Tripartiella Lom, 1959; and Trichodinella Lom, 1963 were reported from freshwater and estuarine habitats (Asmat et al. 1997, 2003a-c, 2005a-b, 2006), Bhouyain et al. 1999, Habib and Asmat, 2008, Kibria et al. 2009, 2010, 2011ab, Habib et al. 2010 a-b, and Kibria and Asmat 2014). During a survey on the species diversity of the trichodinid ciliates from some freshwater and estuarine fishes of Chittagong between January and December 2001 two species of trichodinid ectoparasites belonging to the genera Tripartiella Lomm, 1959 and Trichodina Ehrenberg, 1830 were recorded for the first time in Bangladesh. The ciliates were found, infecting the gills of Rita rita (Hamilton, 1822) and Channa striata (Bloch, 1793). The aims of the present study are to contribute to the protistan gill parasite of fish, and to expand knowledge on the distribution of identified trichodinid ciliates in Bangladesh.

\section{MATERIAL AND METHODS}

The host fishes were collected by using fishing nets from different rivulets of the Karnaphuli River in the Sadarghat area, and a selected pond, locally known as Peerbari Pond, of Chittagong City Corporation area from January to December 2001. Gill scrapings were made at the riverside and the airdried gill scrapings were made, then these were transported to the laboratory. The slides with trichodinid ciliates were impregnated with Klein's dry silver impregnation technique (Klein 1958). Examinations of prepared slides were made under a OSK 9712 T-2 research microscope at 10x 100 magnification. With the exception of the number of denticles and radial pins, all measurements are presented in micrometers $(\mu \mathrm{m})$. Measurements were made according to the recommendations of Lom (1958), Wellborn (1967), Arthur and Lom (1984) and Van As and Basson $(1989,1992)$ (Fig. 1). In order to obtain comprehensive morphological details of the ciliates numerous photomicrographs were taken. The level of infection was measured as low (1-5 ciliate/slide), medium (6-10 ciliate/slide) and high (more than 10 ciliates/slide). 


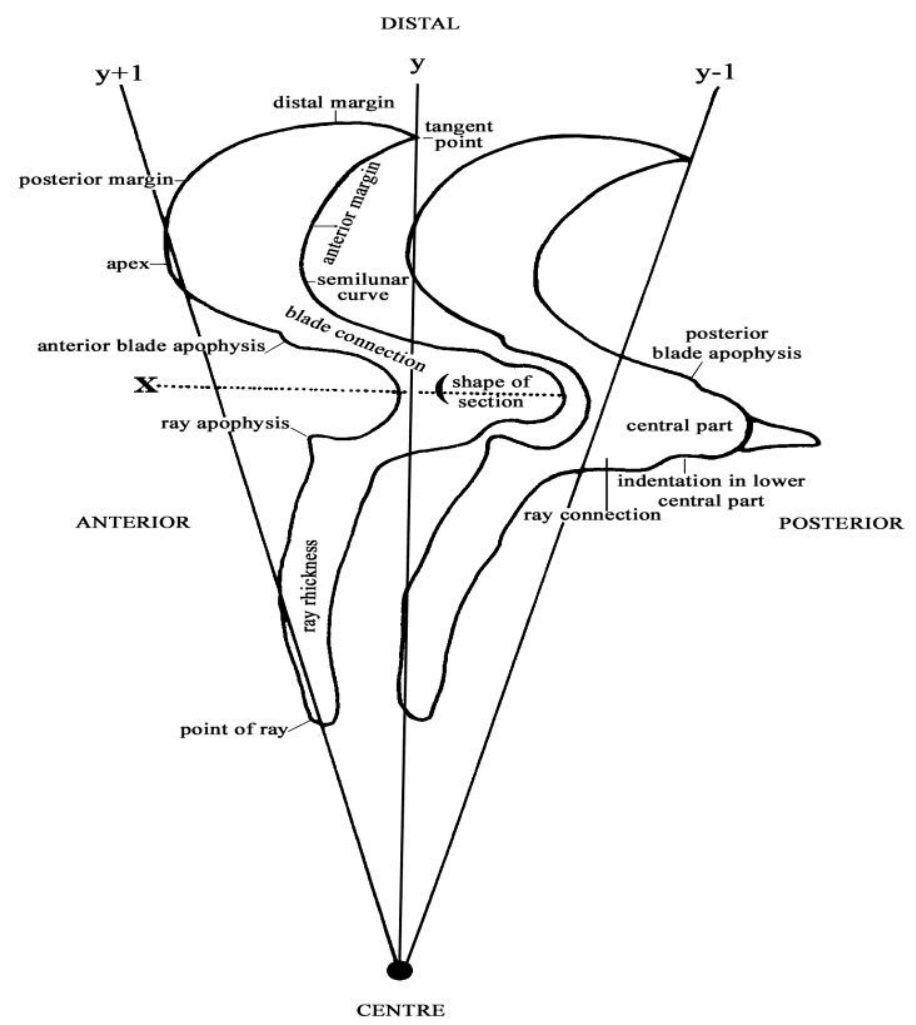

Fig. 1. Diagramatic drawing of trichodinid denticles illustrating the method for description of denticles (after Van As and Basson 1989).

\section{RESULTS AND DISCUSSION}

Tripartiella orthodens Basson and Van As, 1987 (Figs. 2a-b, 3a-b, Table 1)

Host: Rita rita (Hamilton, 1822) (Siluriformes: Bagridae). Locality: Sadarghat area at the Karnaphuli river $\left(22^{\circ} 18 / \mathrm{N} \mathrm{91}{ }^{\circ} 53 / \mathrm{E}\right)$, Chittagong, Bangladesh. Location: Gills. Prevalence: ${ }^{3} / 20$ (15.0\%). Infection: Low. Reference Materials: Lectotype Slide CUZM-RR-KR 1 (prepared on 10/9/2001) containing silver nitrate impregnated is in the Museum of Department of Zoology, University of Chittagong, Chittagong 4331, Bangladesh.

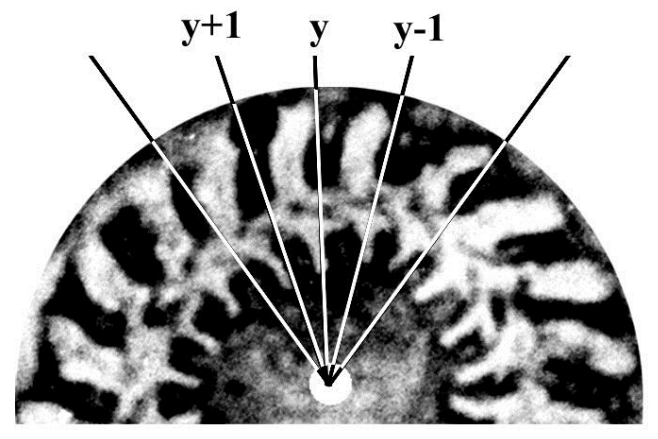

a

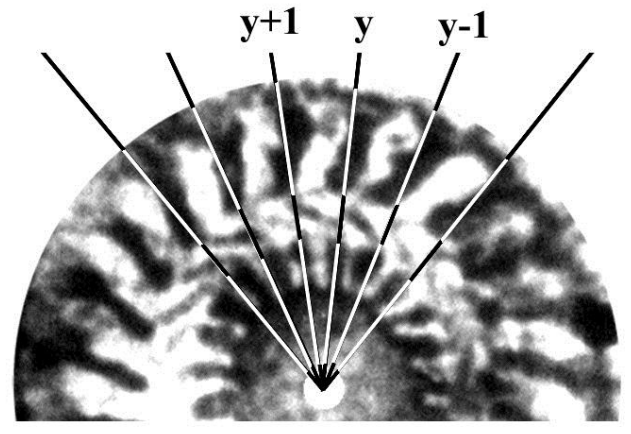

b

Fig. 2 (a-b). Denticles of Tripartiella orthodens Basson and Van As (1987) from Rita rita in Chittagong.

Description: ( $\mathrm{n}=20)$. Small-sized trichodinid with disc-shaped body, diameter 17.1-22.2 (19.4 \pm 6.4$)$;

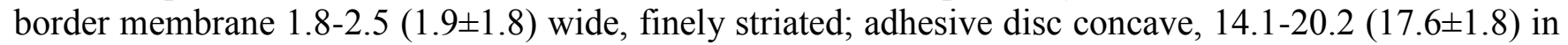


diameter; centre of adhesive disc granular with lightly stained central area, 3.0-4.5 (3.5 \pm 0.6$)$ in diameter; denticulate ring 5.1-10.1 (8.0 1.4$)$ in diameter; number of denticles 19-28 (22.6 \pm 2.1$)$; number of radial

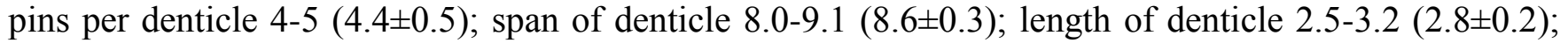
Ray short, straight, slanted posteriorly with a blunt point and tip of ray directed slightly forward; ray apophysis absent, length of ray 2.5-3.2 (2.8 \pm 0.2$)$, and tip of ray directed slightly forward; length of ray 2.5-3.2 (2.8 \pm 0.2$)$, of blade 4.5-5.1 (4.8 \pm 0.2$)$; and width of central part 0.3-0.4 (0.3 \pm 0.1$)$. Adoral ciliary spiral $190-200^{\circ}$.

Denticle morphology: Blade of denticle slightly curved, much longer than ray, swept oblique backwards. Lateral sides of blade almost parallel, but slightly curved and rounded at posterior side. Distal margin lying close to border membrane, rounded, with flat tangent forming a small line with yaxis (Fig. 2a-b). Anterior margin curved and forms angle with $y+1$ axis. Anterior projection welldeveloped, fitting firmly into notch of following denticle and connected to central part by slightly curved section. Posterior margin forms distinct posterior projection (Figs. 3a-b). Central part of denticle spikelike slightly sloped. Ray short, terminating in rounded point, and slightly slanted posteriorly, but remains parallel to y-axis. Ray connection not distinct and hardly distinguishable from ray. Ray short, straight, erect and nearly attached to y axis with a blunt point of ray; and ray apophysis absent.

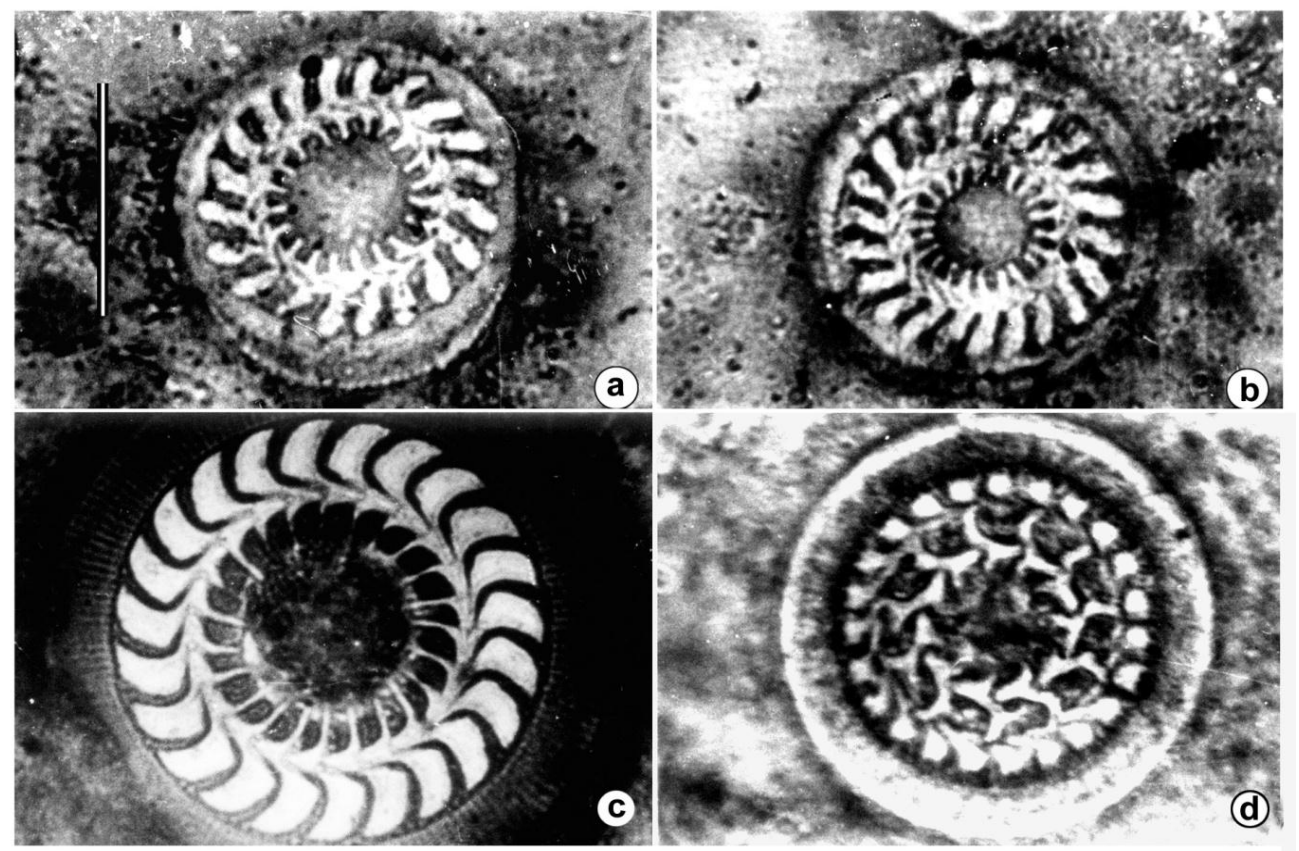

Fig. 3. Photomicrographs of silver impregnated adhesive discs of trichodinids. a-b Tripartiella orthodens Basson and Van As, 1987 from Rita rita; and c adult Trichodina cobitis Lom, 1961; d stage of binary fission of T. cobitis from Channa striata in Chittagong. Scale bar $20 \mu \mathrm{m}$.

Tripartiella orthodens was first identified from the gills of Tilapia rendalli swierstrai by Basson and Van As (1987) at Komati River system in South Africa. Later, it was reported from the gills of freshwater fish Pelteobagrus nitidus in Shapingba, Chongqing area of China (Tang et al. 2013). In the present population we found the same constant characteristics as showed by Basson and Van As (1987) (Fig. 4 a-d). However, the dimensions of the body and the denticle components are remarkably smaller than the South African and Chinese population described by Basson and Van As (1987) and Tang et al. (2013), respectively (Table 1). The present report is the second record of T. orthodens outside South 
Africa and established a new host record, Rita rita for T. orthodens. This finding also extends the known geographic range for this ciliate.

R. rita is widely distributed and important commercial fresh and brackish water fish of Bangladesh. A total of 20 individuals of the host fish was examined to observe the presence of trichodinid ciliates. Three out of twenty $(15.0 \%)$ of the examined $R$. rita were found infected with $T$. orthodens. This ciliate was found invading the gills of host fish species only in September, 2001. Overall the intensity of infection of this ciliate was low.

Table 1. Morphometric comparison of Tripartiella orthodens Basson and Van As, 1987 obtained in the present study with that of Basson and Van As (1987).

\begin{tabular}{|c|c|c|c|}
\hline \multicolumn{2}{|c|}{$\begin{array}{l}\text { Species } \\
\text { (Reference) }\end{array}$} & \multirow{2}{*}{$\begin{array}{c}\begin{array}{c}\text { Tripartiella orthodens } \\
\text { (Basson and Van As 1987) }\end{array} \\
27.6-36.5(32.4+2.9)\end{array}$} & \multirow{2}{*}{$\begin{array}{c}\begin{array}{c}\text { Tripartiella orthodens } \\
\text { (Present paper) }\end{array} \\
17.1-22.2(19.4 \pm 6.4)\end{array}$} \\
\hline \multirow{4}{*}{ Diameter } & Body & & \\
\hline & Adhesive disc & $23.0-31.7(27.4 \pm 2.6)$ & $14.1-20.290(17.6 \pm 1.8)$ \\
\hline & Denticulate ring & $12.8-16.3(14.4 \pm 1.1)$ & $5.1-10.1(8.0 \pm 1.4)$ \\
\hline & Central area & --- & $3.0-4.5(3.5 \pm 0.6)$ \\
\hline \multicolumn{2}{|c|}{ Width of border membrane } & $2.2-3.6(2.6 \pm 0.4)$ & $1.8-2.5(1.9 \pm 0.3)$ \\
\hline \multirow[b]{2}{*}{ Number } & Denticles & $24-28(26)$ & $19-28(22.6 \pm 22.6 \pm 2.1)$ \\
\hline & $\begin{array}{l}\text { Radial pins/ } \\
\text { denticle }\end{array}$ & $5-6(5)$ & $4-5(4.4 \pm 0.5)$ \\
\hline \multicolumn{2}{|c|}{ Span of denticle } & --- & $8.0-9.1(8.6 \pm 0.3)$ \\
\hline \multirow{3}{*}{ Length } & Denticle & $3.3-4.5(3.8 \pm 0.4)$ & $2.5-3.2(2.8 \pm 0.2)$ \\
\hline & Ray & $1.8-3.0(2.5 \pm 0.3$ & $2.5-3.0(2.8 \pm 0.2)$ \\
\hline & Blade & $3.0-5.4(4.2 \pm 0.7)$ & $4.5-5.1(4.8 \pm 0.2)$ \\
\hline \multirow{2}{*}{\multicolumn{2}{|c|}{$\begin{array}{l}\text { Width of central part } \\
\text { Degree of adoral ciliature }\end{array}$}} & $1.2-2.6(1.6 \pm 0.3)$ & $0.3-0.4(0.3 \pm 0.1)$ \\
\hline & & 270 & $190-200$ \\
\hline
\end{tabular}

Trichodina cobitis Lom, 1961 (Figs. 3c-d, 4c-d, Table 2)

Host: Channa striata (Bloch, 1793) (Perciformes: Channidae). Locality: Peerbari Pond, Chittagong City Corporation area (between $22^{\circ} 13^{\prime}$ and $22^{\circ} 27^{\prime}$ north latitudes and in between $91^{\circ} 40^{\prime}$ and east longitudes), Bangladesh. Location: Gills. Prevalence: ${ }^{11} / 70$ (15.7\%), June-September, 2001. Infection: Low. Reference Materials: Lectotype, Slide CUZM-CS-PP (prepared on 7-7-2001) containing silver impregnated specimens are in the collection of the Museum of Department of Zoology, University of Chittagong, Chittagong 4331, Bangladesh.

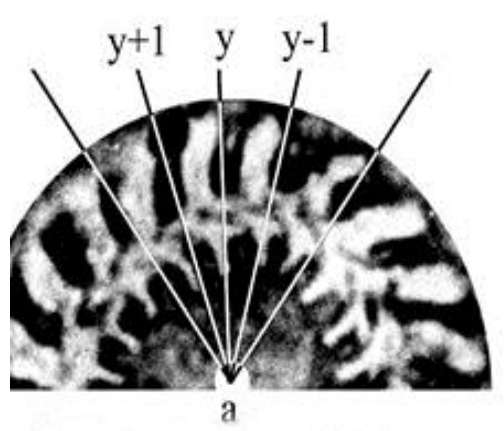

Fig. 4. Diagramatic drawings of denticles of trichodinids. a. Tripartiella orthodens from Rita rita in Chittagong; b. T. orthodens from Tilapia rendalli in South Africa (redrawn from Bassoon and Van As 1987); c. Trichodina cobitis from Channa striata in Chittagong; and d. T. cobitis from Cobitis taenia in Czech Republic (redrawn from Lom 1961). 
Description: $(\mathrm{n}=20)$. Medium-sized, 42.8-63.2 (52.7 \pm 5.5$)$ with and saucer-shaped adhesive disc, 32.6-52.0 (42.7 \pm 5.3$)$. Centre of adhesive disc concave 6.1-13.8 (10.1 \pm 203$)$, dark and uniformly granular when impregnated with silver. Border membrane distinct ribbon-like, 4.1-5.1 (5.0) wide and finely

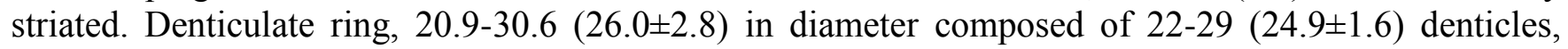
leaving moderate interblade space. Radial pins per denticle 7-9 (7.6 \pm 0.6$)$. span of denticle 11.7-16.3 (14.5 \pm 1.3$)$; length of denticle 5.1-8.3 (7.0 \pm 0.7$)$; Ray short, straight, slanted posteriorly with a blunt point and tip of ray directed slightly forward; ray apophysis absent, and tip of ray directed slightly forward; length of ray 5.1-7.6 (6.5 \pm 0.7$)$, of blade 4.6-6.6 (5.5 \pm 0.6$)$; and width of central part 2.0-3.1 (2.6 \pm 0.5$)$. Adoral ciliature forms a counterclockwise spiral of more than $380^{\circ}$.

Table 2. Morphometric comparison of Trichodina cobitis Lom, 1961 obtained in the present study with that of Basson and Van As (1987).

\begin{tabular}{|c|c|c|c|}
\hline $\begin{array}{l}\text { Species } \\
\text { (Referenc }\end{array}$ & & $\begin{array}{c}\text { Trichodina cobitis } \\
(\text { Lom }(\mathbf{1 9 6 0})\end{array}$ & $\begin{array}{c}\text { Trichodina cobitis } \\
\text { (Present paper) }\end{array}$ \\
\hline \multirow{4}{*}{ Diameter } & Body & $41-58(55)$ & $42.8-63.2(52.7 \pm 5.5)$ \\
\hline & Adhesive disc & $32-38(45)$ & $32.6-52.0(42.7 \pm 5.3)$ \\
\hline & Denticulate ring & $20-24(21)$ & $20.9-30.6(26.0 \pm 2.8)$ \\
\hline & Central area & - & $6.1-13.8(10.1 \pm 2.3)$ \\
\hline Width of $\mathrm{b}$ & rder membrane & 5.5 & $4.1-5.1(5.0 \pm 0.4)$ \\
\hline \multirow{2}{*}{ Number } & Denticles & $23-30(25)$ & $22-29(24.9 \pm 1.6)$ \\
\hline & Radial pins/denticle & $8-10$ & $7-9(7.6 \pm 0.6)$ \\
\hline \multicolumn{2}{|c|}{ Span of denticle } & -- & $11.7-16.3(14.5 \pm 1.3)$ \\
\hline \multirow{3}{*}{ Length } & Denticle & 8 & $5.1-8.3(7.0 \pm 0.7)$ \\
\hline & Ray & 6 & $5.1-7.6(6.5 \pm 0.7)$ \\
\hline & Blade & 5.5 & $4.6-6.6(5.5 \pm 0.6)$ \\
\hline \multirow{2}{*}{\multicolumn{2}{|c|}{$\begin{array}{l}\text { Width of central part } \\
\text { Degree of adoral ciliature }\end{array}$}} & 2.5 & $2.0-3.1(2.6 \pm 0.5)$ \\
\hline & & - & more than $380^{\circ}$ \\
\hline
\end{tabular}

Denticle morphology: Blade of denticle angular filling most of space between $y+1$ axis. Distal margin truncated, running parallel to border membrane and lying away from it. Tangent point sharp, situated at same level or slightly above distal margin. Borders of blades almost parallel, so that blade of same width throughout its length, and follow each other at close intervals (Fig. 3c). Anterior margin slopes angularly and forms a conical apex at base of blade. Apical depression, although developed, never impregnates, but touches $y+1$ axis, rarely crosses this line. Anterior blade apophysis is not clearly visible. Posterior margin of blade smoothly curves to form a shallow, elongated semilunar curve with deepest point at same level as apex (Fig. 4c-d). Blade connection is well developed and thicker than ray. Posterior blade apophysis is absent. Central part stout, triangular with bluntly rounded point that extends more than halfway past y-1 axis and interposed firmly with corresponding denticle. Section of central part above and below x-axis is similar. Ray connection short and thin, with antero-distally directed ray apophysis. Ray slightly longer than blade, slender, of uniform thickness with slight constriction at base just below ray apophysis and bears a distinct central groove. Ray straight, sometimes slightly curved in posterior direction, but lying parallel to y axes in both the cases and ends in rounded point.

Intraspecific variability: In the present material, the shape of blade displayed no considerable variability. The ray, typically directed centrally, was occasionally observed to be slightly curved posteriorly. Young specimens were found during the present study period (Fig. 3d). Trichodina cobitis Lom, 1961 was originally described as Trichodina nigra f. cobitis by Lom (1961) from the gills of Cobitis taenia in river Luznice near Trebon, Czechoslovakia (at present Czech Republic). The use of the concept of subspecies for members of the genus Trichodina has become obsolete (Lom 1970). The 
profusion of new species recently described from freshwater fishes has obscured the relative level of distinctness existing between the subspecies of Trichodina nigra such that they are now no longer considered to be more closely related to each other than to other closely allied members of the genus (Arthur and Lom 1984). Based on this conception T. nigra f. cobitis is regarded as a separate taxon, $T$. cobitis Lom, 1961. Ozer and Ozturk (2015) recently recorded T. cobitis on Cobitis taenia as new record from Lower Kizilirmak Delta for Turkish trichodinid fauna. The species may be characterized by having truncated distal margin, almost parallel lateral margins of the blade, so that the blade is of the same width throughout its length, and follow each other at close intervals; and the rays do not taper towards their ends, their greatest width being approximately in the middle. The specimens collected during the present study are identical in characters and shape as presented by Lom (1960). The present report of $T$. cobitis from $C$. striata as well as from the south Asia appears to be the first record. The morphometric comparisons of T. cobitis are presented in Table 2.

The host fish was almost regularly examined between January and December, 2001. But the described species was encountered only from June to September, 2001. T. cobitis was found to infect eleven out of 70 specimens (15.7\%) of host fish examined. The intensity of infection was low.

\section{ACKNOWLEDGEMENTS}

The authors are grateful to Dr. Nurul Anwar, Professor of Microbiology, University of Chittagong, Bangladesh for helping in photomicrography.

\section{REFERENCES}

Arthur, J. R. and J. Lom. 1984. Trichodinid Protozoa (Ciliophora: Peritrichida) from freshwater fishes of Rybinsk Reservoir, USSR. J. Protozool. 31: 82-91.

Asmat, G. S. M. and N. Sultana. 2005a. Four New species of Trichodina Ehrenberg, 1830 (Ciliophora: Trichodinidae) from Bangladeshi fish, Chittagong. Pakistan J. Biol. Sci. 8: 895-900.

Asmat, G. S. M., A. K. M. Hafizuddin and M. M. A. Habib. 2003c. Trichodina sylhetensis sp. n. (Ciliophora: Trichodinidae) from the Mud Perch, Nandus nandus (Hamilton-Buchanan, 1822) (Nandidae) in Sylhet. Pakistan J. Biol. Sci. 6: 1774-1777.

Asmat, G. S. M., A. M. Bhouyain and P. S. Siddiqua. 1997. First record of a species of Paratrichodina Lom, 1963 (Mobilina: Urceolariidae) from Mystus vittatus (Bloch) in Bangladesh. Environ. Ecol. 15: $843-845$.

Asmat, G. S. M., B. Hoque and N. Mohammad. 2006. A New Species of Trichodina Ehrenberg, 1830 (Ciliophora: Trichodinidae) from the Long Whiskered Catfish, Mystus gulio (Hamilton, 1822) (Siluriformes: Bagridae) in Chittagong, Bangladesh. Res. J. Fish Hydrobiol. 1: 28-31.

Asmat, G. S. M., F. Afroz and N. Mohammad. 2005b. Four new species of Trichodina Ehrenberg, 1830 (Ciliophora: Trichodinidae) from Bangladeshi fishes. Res. J. Agri. Biol. Sci. 1: 23-29.

Asmat, G. S. M., M. M. Kibria and L. Naher. 2003b. Trichodina gulshae sp. n. (Ciliophora: Trichodinidae) from the Gangetic Mystus, Mystus cavasisus (Hamilton-Buchanan, 1822) (Bagridae) in Chittagong. Pakistan J. Biol. Sci. 6: 1608-1611.

Asmat, G. S. M., N. Mohammad and N. Sultana. 2003a. Trichodina anabasi sp. n. (Ciliophora: Trichodinidae) from climbing perch, Anabas testudineus (Bloch, 1795) (Anabantidae) in Chittagong. Pakistan J. Biol. Sci. 6: 269-272. 
Basson, L. and J. G. Van As. 1987. Trichodinid (Ciliophora: Peritricha) gill parasites of freshwater fish in South Africa. Syst. Parasitol. 9: 143-151.

Bhouyain, A. M., G. S. M. Asmat and P. S. Siddiqua. 1999. Record of Tripartiella copiosa Lom, 1959 (Mobilina: Trichodinidae) from the gills of Mystus vittatus (Bloch) in Bangladesh. Chittagong Univ. J. Sci. 23: 67-73.

Habib, M. M. A. and G. S. M. Asmat. 2008. Record of Trichodinella epizootica (Raabe) Šrámek-Hušek (Ciliophora: Trichodinidae) from a major carp, Labeo rohita from Tanguar Haor in Sunamganj. $J$. Asiat. Soc. Bangladesh, Sci. 34: 89-92.

Habib, M. M. A., A. Chowdhury and G. S. M. Asmat. 2010a. Record of Trichodina japonica and Trichodina ngoma from the freshwater bagrid host fishes of Tanguar Haor in Sylhet, Bangladesh. $J$. Asiat. Soc. Bangladesh, Sci. 36: 147-153.

Habib, M. M. A., M. M. Kibria and G. S. M. Asmat. 2010b. On two Tripartiella sp. from the freshwater fishes of Tanguar Haor in Sylhet, Bangladesh. J. Asiat. Soc. Bangladesh, Sci. 36: 163-170.

Kibria, M. M. and G. S. M. Asmat. 2014. Trichodinid ectoparasites (Ciliophora: Trichodinidae) from the historical Bostami Pond of Chittagong, Bangladesh. In: N. Gupta and D. K. Gupta (eds.). Modern Parasitology. Narendra Publishing House, Delhi, India, pp. 39-57.

Kibria, M. M., H. Islam and G. S. M. Asmat. 2011a. Trichodina johniusi sp. n. (Ciliophora: Trichodinidae) from Johnius coitor (Hamilton, 1822) in the Shitalakshya River, Bangladesh. Wiadomoœci Parazytologiczne. 57: 265-270.

Kibria, M. M., H. Islam, M. M. A. Habib and G. S. M. Asmat. 2010. Trichodinid Ectoparasites (Ciliophora: Trichodinidae) from the Day's Mystus, Mystus bleekeri (Day, 1877) and the Tank Goby, Glossogobius giuris (Hamilton, 1822) in the Shitalakhsya River, Bangladesh. Wiadomooci Parazytologiczne. 56: 153-161.

Kibria, M. M., H. Islam, M. M. A. Habib and L. C. Shutradhar. 2011b. Trichodinid ectoparasites (Ciliophora: Trichodinidae) from the gills of freshwater fishes in the Shitalakhsya River, Bangladesh. Proceedings of the 22nd National Congress on Parasitology. 1: 135-149.

Kibria, M. M., N. Sultana, M. M. A. Habib, N. Sharmin and G. S. M. Asmat. 2009. Two trichodinid ciliates (Ciliophora: Trichodinidae) from Oreochromis mossambicus (Peters, 1852) in Bangladesh. Bangladesh J. Marine Sci. Fish. 1: 63-70.

Klein, B. M. 1958. The dry silver method and its proper use. J. Protozool. 5: 99-103.

Lom, J. 1958. A contribution to the systematics and morphology of endoparasitic trichodinids from amphibians with a proposal of uniform specific characteristics. J. Protozool. 5: 251-263.

Lom, J. 1961. Ectoparasitic trichodinids from fresh water fish in Czechoslovakia. Vestn. Cesk. Spol. Zool. 25: 215-228.

Lom, J. 1970. Trichodinid ciliates (Peritrichida: Urceolariidae) from some marine fishes. Folia Parasitol. 17: 113-125.

Ozer, A. and T. Ozturk. 2015. Trichodinid fauna of freshwater fishes with infestation indices in the Lower Kizilirmak Delta in Turkey and a checklist of trichodinids (Ciliophora: Trichodinidae) in Turkish waters. Turk. J. Zool. 39: 749-761. 
Tang, F., Y. Zhao and C. Liu. 2013. First records of three Tripartiella species (Ciliophora, Oligohymenophora, Peritrichida) from freshwater fishes along Yangtze River in China. Zootaxa. 3681(1): 169-174.

Van As, J. G. and L. Basson. 1989. A further contribution to the taxonomy of the Trichodinidae (Ciliophora : Peritrichida) and a review of the taxonomic status of some ectoparasitic trichodinids. Syst. Parasitol. 14: 157-179.

Van As, J. G. and L. Basson. 1992. Trichodinid ectoparasites (Ciliophora: Peritrichida) of freshwater fishes of the Zambesi River System, with a reappraisal of host specificity. Syst. Parasitol. 22: 81109.

Wellborn, T. L. Jr. 1967. Trichodina (Ciliata: Urceolariidae) of freshwater fishes of the southeastern United States. J. Protozool. 14: 399-412. 